\title{
必要加速度ベクトルに基づいた，航空機の飛行経路制御技術*1 A Flight-Path Control of Aircraft Based on Required Acceleration Vector
}

\author{
芳 谷 直 治*2 \\ Naoharu Yoshitani
}

Key Words : Flight Dynamics, Guidance and Control, Flight-Path Control, Acceleration Vector

\begin{abstract}
This paper presents an automatic flight-path control of aircraft. In the control, a desired flight trajectory is first determined as a sequence of straight lines, arcs and spirals in the three-dimensional space. Commands and command rates of heading and flight-path (climb) angles are then obtained from the desired trajectory. A required acceleration vector of the aircraft is calculated based on the command rates and angle deviations. Desired roll, pitch and yaw rates are then obtained by acceleration controller and are fed to attitude control. The feedback control of acceleration employs conventional PID control technology, without using inverse dynamics of the aircraft, and the attitude control can employ any existing control technologies suitable for the aircraft to be controlled. These make the proposed control relatively simple and easy to implement. Numerical simulations illustrate the effectiveness of the control.
\end{abstract}

\section{記 号 の 説 明}

$\phi, \theta, \psi:$ ロール角，ピツチ角，ヨー角

$p, q, r:$ ロール角速度，ピッチ角速度，ヨ一角速度

$\alpha, \beta$ : 迎角，横滑り角

$\phi_{\mathrm{b}}:$ バンク角 (速度ベクトル回り)

$\lambda, \gamma:$ 進行方向の方位角 (上から見て時計回りが正), 経路角 (上昇角)

$\vec{g}:$ 重力加速度ベクトル,$g=|\vec{g}|$

$\vec{V}_{\mathrm{a}}:$ 航空機速度ベクトル, $V_{\mathrm{a}}=\left|\vec{V}_{\mathrm{a}}\right|$

$\vec{\zeta}:$ 航空機位置， $\vec{\zeta}$ の軌跡が飛行経路を表わす．

$\vec{\xi}_{\mathrm{c}}$ : 方向ベクトル指令值 (単位ベクトル), 航空機 進行方向の指令值を表わす．

$x^{\mathrm{B}} y^{\mathrm{B}} z^{\mathrm{B}}$ 系: 機体軸系

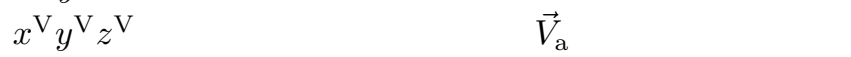
およびこれらの軸に垂直下方向を表わす座標 系 (速度軸系)

$(\cdot)^{\mathrm{V}}: x^{\mathrm{V}} y^{\mathrm{V}} z^{\mathrm{V}}$ 系で表わしたベクトルなど

$\vec{a}_{\mathrm{c}}^{\mathrm{V}}$ : 航空機加速度指令值ベクトル $\left(y^{\mathrm{V}} z^{\mathrm{V}}\right.$ 面内 $)$

$(\cdot)_{\mathrm{c}}$ : 指令值 (目標値)

$(\cdot)^{\mathrm{T}}:$ ベクトルや行列の転置

$(\cdot)$ : 時間に関する微分

第 1 図に機体軸系, 速度ベクトルとおもな角度, 角速度 を示す．

\footnotetext{
*1 C 2007 日本航空宇宙学会

平成 16 年 10 月 7 日, 第 42 回飛行機シンポジウムにおいて発 表. 平成 18 年 2 月 8 日原稿受理

*2 帝京大学理工学部航空宇宙工学科
}

1. は じめ に

無人機の飛行や人間パイロットの負荷低減のためには, 航 空機を 3 次元空間内の目標経路に沿って自動的に飛行させ る技術，すなわち自動経路制御の技術が必要である.自動 経路制御技術については従来，いくつかの方法が提案され ている( ${ }^{(2)}$. 弚れらは航空機運動の逆システムを用いて, 舵 面角度などの操作量を求めており, フィードバック制御で は空力微係数などの値を必要とする.

著者はこれまで, 自動経路制御の前段階として, 航空機の 方位角と経路角の自動制御技術を提案した5) 。この方位角・ 経路角制御では，進行方向に垂直な面内において航空機に 必要な加速度べクトルを加速度指令值としてまず求め, 光 れに基づいてロール, ピッチ， ヨーの角速度指令值を PID (比例十積分十微分) 制御を基本とした制御則で算出して, 加速度制御の操作量とする.これら指令值は, 弚の下位の 姿勢制御の目標值となる. 加速度制御の基本的考え方は, 必 要な加速度を適切なバンク角とピッチ角速度，ヨ一角速度 によって達成することである．

本稿で提案する飛行経路制御は, 上記方位角・経路角制 御を内部ループに含み，弚の外側に飛行経路制御のループ を付加したものである.制御系全体への入力は目標飛行経 路であり，これは 3 次元空間内で直線，円弧，またはらせ んを滑らかに接続した曲線として前もって与える. 本制御 の基本的考え方は，航空機を目標経路に沿って飛行させる ための下記の条件 C1〜C3 が達成されるように，方位角と 経路角の指令值をまず求め，これらを用いて飛行方向に垂 直な面内での必要加速度を求めることである．

$\mathrm{C} 1 ：$ 航空機位置を目標経路に一致させる . 
$\mathrm{C} 2$ : 航空機飛行方向を目標経路方向（目標経路の接線方向） に一致させる 。

C3 : 航空機飛行方向変化率 (飛行経路曲率に対応) を目標 経路の方向変化率に一致させる .

条件 $\mathrm{C} 1 ， \mathrm{C} 2$ の達成はフィードバック制御により行うが， 条件 C3 の達成は，経路制御の時間遅れを打ち消すために， 所定時間だけ先の目標経路曲率を用いる予見フィードフォ ワード制御により行う。

方位角と経路角の指令值を求めた後の制御計算は，著者 がこれまでに提案した制御と同樣であり，フィードバック 制御には PID 制御則を用いる.一方, 航空機速度に関して は，目標経路上各点において目標速度を定めておき，エン ジン出力指令值を操作量として, PID 制御則などの従来と 同樣の方式により速度制御を行う。

これまでに提案された飛行経路制御技術と比べたときの， 本制御の特徵・利点を以下に示す。

$\mathrm{A} 1$ : フィードバック制御則は設計・調整法か確立している PID 制御則に基づいており，制御計算において航空機の 逆システム (逆動力学) や空力微係数は不必要である.

$\mathrm{A} 2$ : 飛行経路曲率が予見フィードフォワード方式により制 御されるため, 経路制御の時間遅れはほとんど打ち消さ れる。

A3 : 本制御の下位の姿勢制御は, 航空機固有の形態や特性

に大きく依存する .この姿勢制御には, 各航空機ごとに 信頼性か確立されている従来制御方式を兴のまま用いる ことができるため, 本制御の導入は既存制御の大きな変 更なしに可能であり, 兴の分安全性が高い .

本制御の有効性はシミュレーションで確認された .

\section{2. 制 御 方 法}

制御系のブロック線図を第 2 図に示す．制御系は階層構 造をしており, 最上位の Flight-Path Controller（経路コ

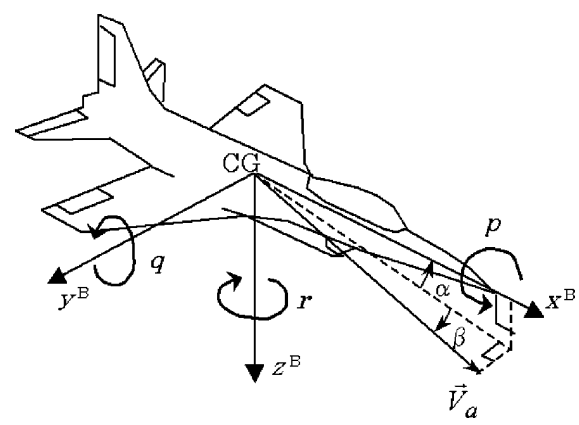

第 1 図 機体軸と速度，角速度
ントローラ) では, 飛行経路 $\vec{\zeta}$ が目標経路 $\vec{\zeta}_{\mathrm{c}}$ に追従するよ うに,航空機の方位角·経路角指令值 $\left(\lambda_{\mathrm{c}}, \gamma_{\mathrm{c}}\right)$ を算出する. つぎの Heading and Flight-Path Angle Controller (方位 角·経路角コントローラ) では， $\lambda_{c}, \gamma_{c}$ を用いて加速度指令 値 $\vec{a}_{\mathrm{c}}^{\mathrm{V}}$ (必要加速度) を算出する. 兴の下位の Acceleration Controller（加速度コントローラ）では，加速度指令值に 基づいてバンク角指令值 $\phi_{\mathrm{bc}}$ とピッチ・ヨー角速度指令值 $q_{\mathrm{c}}, r_{\mathrm{c}}$ を算出し，バンク角指令值からはロール角速度指令 值 $p_{\mathrm{c}}$ を求めて, $p_{\mathrm{c}}, q_{\mathrm{c}}, r_{\mathrm{c}}$ を速度指令值 $V_{\mathrm{ac}}$ とともに出 力する . 最下位の Attitude \& Velocity Controller (姿勢 · 速度コントローラ) では，エルロン・エレベータ・ラダー などの制御舵面を操作して $p, q, r$ を, エンジン出力を操 作して速度 $V_{\mathrm{a}}$ を制御する。

つぎに各部分ごとに制御アルゴリズムを示す．

2.1 目標経路の生成 経路コントローラへの入力であ る目標経路は, 3 次元空間における曲線として, 前もって生 成する.目標経路に沿った飛行を実現させるためには，目 標経路 (Desired Path) は少なくとも以下の条件を満たす ことが望ましい。

DP1：経路が滑らかである，すなわち経路の 1 次微分が連 続的に変化する。

従来の経路制御技術では, 十分な滑らかさを確保するた めに 3 次スプライン関数により目標経路を定める手法も提 案されている21. ここでは条件 DP1 と経路生成の容易さと を考慮して，直線，円弧，らせんなどを滑らかに接続した 曲線を目標経路とする。

また，目標経路が飛行性能の限界を超えている，あるい は突発性の外乱発生, などの理由で飛行経路が目標経路か ら大きくはずれる場合でも，本制御を用いれば，後述のシ ミュレーション結果に示すように，弚の後は滑らかに目標 経路に戻ることができる．

2.2 経路コントローラ 制御周期ごとの各制御時刻に おいて経路コントローラは, 前節 1 の 11 C 3 に記した条 件を総合的に考慮して，制御計算を行う.たとえば航空機 が目標経路から離れている場合は, 目標経路に近づけるこ とを優先する．すなわち，C2，C3 よりも $\mathrm{C} 1$ を優先する . 航空機が目標経路に近づいたならば, 飛行経路を滑らかに 目標に一致させるために，C2，C3 の優先度を大きくする． 以上の考え方にしたがった，具体的な計算方法を以下に述 べる.

2.2 .1 方向ベクトル指令值の算出 各制御時刻における 計算ではまず, 航空機現在位置 $\vec{\zeta}$ に最も近い目標経路上の 点を求め，「基準点」 $\vec{\zeta}_{\text {ref }}$ とする.ただし基準点は目標経路

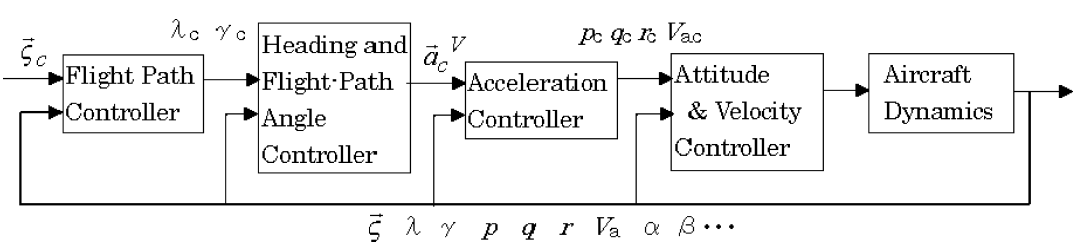

第 2 図 制御系ブロック線図 
上を後戻りはしないものとし, 直前に求めた点から前方に おいて求める. 基準点における目標経路の接線方向を以後 「目標経路方向」と呼び，この方向の単位ベクトルを $\vec{\xi}_{\mathrm{ref}}$ と 表わす．

つぎに経路上を基準点から所定距離 $d_{\mathrm{aim}}, d_{\mathrm{ff}}$ だけ進ん だ点を弚れぞれ，「目標点」 $\vec{\zeta}_{\mathrm{aim}},\left\ulcorner\mathrm{FF}\right.$ 点」 $\vec{\zeta}_{\mathrm{ff}}$ とする.目 標点は, 航空機が目標経路から離れているときに位置目標 とする点である . $d_{\mathrm{aim}}$ の值は位置誤差 $\left\|\vec{\zeta}_{\mathrm{ref}}-\vec{\zeta}\right\|$ に比例 させ , 速度に比例した所定の上限值以内に制限する . 航空 機位置 $\vec{\zeta}$ から目標点 $\vec{\zeta}_{\mathrm{aim}}$ 方向の単位ベクトルは $\vec{\xi}_{\mathrm{aim}}$ で表 わす．

一方 FF 点での経路曲率は, 航空機が目標に沿って飛行 しているときの飛行経路の目標曲率となる.$d_{\mathrm{ff}}$ は速度に比 例させる. 以上述べた $d_{\mathrm{aim}}, d_{\mathrm{ff}}$ は次式で求める .

$$
\begin{aligned}
& d_{\text {aim }}=\min \left\{t_{\mathrm{amx}} V_{\mathrm{a}}, \quad r_{\mathrm{de}} e_{\zeta}\right\} \\
& d_{\mathrm{ff}}=t_{\mathrm{ff}} V_{\mathrm{a}}
\end{aligned}
$$

こニで

$$
e_{\zeta}=\left\|\vec{\zeta}_{\text {ref }}-\vec{\zeta}\right\|
$$

ただし，

$e_{\zeta}:$ 位置制御誤差

$t_{\mathrm{amx}}: d_{\mathrm{aim}}$ だけ進むための所要時間の上限值, 正の定数

$r_{\mathrm{de}}$ : 上記所要時間が上限值以下のときの, $d_{\mathrm{aim}}$ と位置制 御誤差 $e_{\zeta}$ との比を定める定数

$t_{\mathrm{ff}}: d_{\mathrm{ff}}$ だけ進むための所要時間, 正の定数

目標経路が直線の場合の, 上記 (1) 式の意味を述べる . 位置 誤差 $e_{\zeta}$ が $\left(t_{\mathrm{amx}} V_{\mathrm{a}} / r_{\mathrm{de}}\right)$ 以下のときは目標点と基準点との 距離 $d_{\mathrm{aim}}$ は位置誤差 $e_{\zeta}$ に比例し, 比例係数が $r_{\mathrm{de}}$ である 一方， $e_{\zeta}$ が $\left(t_{\mathrm{amx}} V_{\mathrm{a}} / r_{\mathrm{de}}\right)$ を超えるときは $d_{\mathrm{aim}}=t_{\mathrm{amx}} V_{\mathrm{a}}$ が成立し，これは $d_{\text {aim }}$ をほぼ一定として，航空機を早く目 標経路に近づけることを意味する。

つぎに, 航空機の方向ベクトル指令値 $\vec{\xi}_{\mathrm{c}}$ (単位ベクトル) を次式で求める.

$$
\begin{aligned}
& \vec{\xi}_{\mathrm{c}}=\frac{\vec{\xi}_{\mathrm{c} 1}}{\left\|\vec{\xi}_{\mathrm{c} 1}\right\|} \\
\text { ここで } & \vec{\xi}_{\mathrm{c} 1}=w_{\mathrm{aim}} \vec{\xi}_{\mathrm{aim}}+\left(1-w_{\mathrm{aim}}\right) \vec{\xi}_{\mathrm{ref}}
\end{aligned}
$$

(5) 式右辺第 1 項は目標点をめざす位置制御（条件 C1）の ための指令を，第 2 項は飛行方向制御（条件 $\mathrm{C} 2$ ) のための 指令を表わす . $w_{\text {aim }}$ は位置制御の重みを表わし，第 3 図の ように位置制御誤差 $e_{\zeta}$ に比例させて, 0 と 1 の間て変化さ せる .

第 3 図において $t_{\mathrm{wa}}$ は正定数で, 適切に值を定める . $e_{\zeta}$ が大きいほど $w_{\mathrm{aim}}$ は大きくなり，条件 $\mathrm{C} 1$ の優先度は高く， $\mathrm{C} 2$ の優先度は低くなる $. e_{\zeta} \geq t_{\mathrm{wa}} V_{\mathrm{a}}$ のときは $w_{\mathrm{aim}}=1$ となって，C2 は考慮されない．このとき後述の $(7)$ 式より， 条件 C3 も考慮されない。

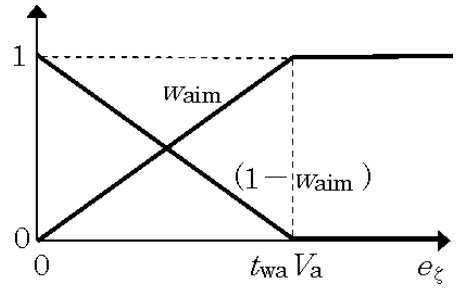

第3 図 位置制御重み $w_{\mathrm{aim}}$

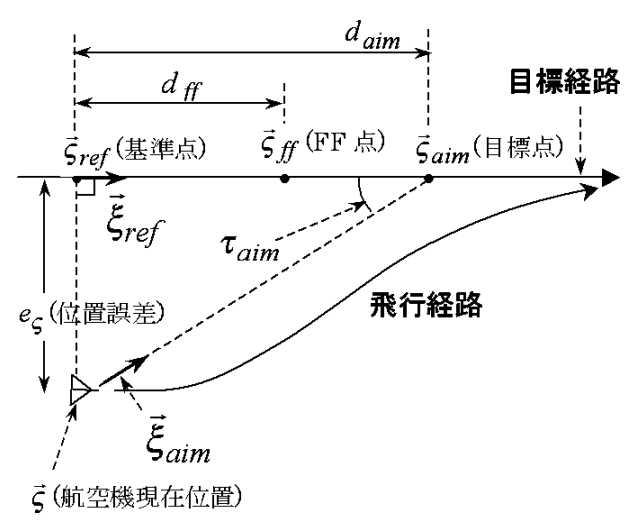

第4图 目標経路と飛行経路の一例

第 4 図に, 目標経路が直線の場合の飛行経路と各点の幾 何学的位置関係の一例を図示する . (4) 式を用いてべクト ル $\vec{\xi}_{\mathrm{c}}$ を求めることにより, 飛行経路は図のように滑らかに 目標経路に一致する.図は $d_{\mathrm{aim}}>d_{\mathrm{ff}}$ の場合の例であり， 逆の場合もありうる．

ベクトル $\vec{\xi}_{\mathrm{c}}$ の方向から, 方位角指令值 $\lambda_{\mathrm{c}}$ と経路角指令 值 $\gamma_{\mathrm{c}}$ が算出される. 以後の処理は以前に提案した方位角・ 経路角制御5) と同樣であり，以下に概略を述べる。

2.2.2 加速度指令值（必要加速度）の算出 実際の方位 角 $\lambda$, 経路角 $\gamma$ と，弚れらの指令值 $\lambda_{\mathrm{c}}, \gamma_{\mathrm{c}}$ とから，まず 進行方向 (飛行方向) 制御偏差を球面幾何学の定理を用い て求め, $x^{\mathrm{V}} y^{\mathrm{V}} z^{\mathrm{V}}$ 系 (速度軸系) の $y^{\mathrm{V}} z^{\mathrm{V}}$ 面内のベクトル $\vec{e}_{\mathrm{v}}^{\mathrm{V}}$ で表わす．つぎに同じ面内の目標加速度べクトル $\vec{a}_{\mathrm{c}}^{\mathrm{V}}$ の フィードバック成分 $\vec{a}_{\mathrm{fb}}^{\mathrm{V}}$ を, PID 制御の操作量として次式 で求める.

$$
\vec{a}_{\mathrm{fb}}^{\mathrm{V}}=V_{\mathrm{a}}\left(K_{\mathrm{aP}} \cdot \vec{e}_{\mathrm{v}}^{\mathrm{V}}+K_{\mathrm{aI}} \cdot \vec{S}_{\mathrm{e}}^{\mathrm{V}}+K_{\mathrm{aD}} \cdot \dot{\vec{e}}_{\mathrm{v}}^{\mathrm{V}}\right)
$$

ここで $K_{\mathrm{aP}}, K_{\mathrm{aI}}, K_{\mathrm{aD}}$ は制御ゲインであり，適当な定数 に定める. $\vec{S}_{\mathrm{e}}^{\mathrm{V}}$ は $\vec{e}_{\mathrm{v}}^{\mathrm{V}}$ の時間的積算値 (積分値) に相当し， $\dot{\vec{e}}_{\mathrm{v}}$ は $\vec{e}_{\mathrm{v}}^{\mathrm{V}}$ の時間微分である.

一方, $\vec{a}_{\mathrm{c}}^{\mathrm{V}}$ のフィードフォワード成分 $\vec{a}_{\mathrm{ff}}^{\mathrm{V}}$ は次式で算出 する .

$$
\vec{a}_{\mathrm{ff}}^{\mathrm{V}}=\vec{a}_{\mathrm{curv}}^{\mathrm{V}} V_{\mathrm{a}}\left(1-w_{\mathrm{aim}}\right) \max \left\{0, \cos \left\|\vec{e}_{\mathrm{v}}^{\mathrm{V}}\right\|\right\}
$$

$\vec{a}_{\mathrm{ff}}^{\mathrm{V}}$ の大きさは, 航空機が目標経路から離れるほど，また進 行方向が目標経路方向からはずれるほど，小さくする．こ こで $\vec{a}_{\mathrm{curv}}^{\mathrm{V}}$ は, 単位速度指令ベクトル $\vec{V}_{\mathrm{ac}} /\left\|\vec{V}_{\mathrm{ac}}\right\|$ の回転 によって生じる $y^{\mathrm{V}} z^{\mathrm{V}}$ 面内のべクトルであり， $\mathrm{FF}$ 点にお ける目標経路曲率実現のために必要な加速度を表わす．航 
空機がほぼ目標経路方向に飛行しているときは, $\vec{a}_{\mathrm{curv}}^{\mathrm{V}}$ を $\left(y^{\mathrm{V}},-z^{\mathrm{V}}\right)$ 成分で表わすとつぎのようになる $\left.{ }^{5}\right)$.

$$
\vec{a}_{\text {curv }}^{\mathrm{V}}=\left[\begin{array}{ll}
\dot{\lambda}_{\mathrm{c}} \cos \gamma_{\mathrm{c}} & \dot{\gamma}_{\mathrm{c}}
\end{array}\right]^{\mathrm{T}}
$$

2.3 加速度コントローラ 加速度制御の詳細は, 著者 の以前の論文5) に記載されているので, 以下に概要を記す。 ここではまず，バンク角指令值 $\phi_{\mathrm{bc}}$ を求める．弚のための 基本的考え方は, 文献 1 3) と同樣に, 前節で求めた必要 加速度 $\vec{a}_{\mathrm{c}}^{\mathrm{V}}$ を，おもにピッチ角速度による揚力方向加速度 で達成することである .この場合揚力は， $\vec{a}_{\mathrm{c}}^{\mathrm{V}}$ を発生させる とともに, 重力加速度の $z^{\mathrm{V}}$ 成分 $g \cos \gamma$ を相殺するために 必要である. 重力相殺べクトル $\left[(-z)^{\mathrm{V}}\right.$ 方向 $]$ を $\vec{g}_{\mathrm{c}}^{\mathrm{V}}$ とす ると，揚力加速度ベクトル $\vec{a}_{\mathrm{cg}}^{\mathrm{V}}(=[$ 揚力] $/[$ 質量] $)$ は

$$
\vec{a}_{\mathrm{cg}}^{\mathrm{V}}=\vec{a}_{\mathrm{c}}^{\mathrm{V}}+\vec{g}_{\mathrm{c}}^{\mathrm{V}}
$$

となる . 揚力は $\vec{a}_{\mathrm{cg}}^{\mathrm{V}}$ の方向に向ける必要があり, $\vec{a}_{\mathrm{cg}}^{\mathrm{V}}$ と $(-z)^{\mathrm{V}}$ 軸との角度差が $\phi_{\mathrm{bc}}$ になる。

つぎにロール角速度指令值 $p_{\mathrm{c}}$ は, 実際のバンク角 $\phi_{\mathrm{b}}$ を $\phi_{\mathrm{bc}}$ に一致させるように, PID 制御則で求める。ピッチ・ ヨ一角速度指令值 $q_{\mathrm{c}}, r_{\mathrm{c}}$ は乥れ光れ， $\vec{a}_{\mathrm{c}}^{\mathrm{V}}$ のピッチ，ヨー 方向成分に基づいて求める. 兴の後 $q_{\mathrm{c}}$ については, 迎角 $\alpha$ と，重心に加わる $\mathrm{G}$ フォース $\left((-z)^{\mathrm{B}}\right.$ 軸方向加速度) とが 所定の上下限值を超えないように, 上下限制限を行う .

2.4 姿勢・ 速度コントローラ 姿勢・速度コントローラ には, 前節で求めた $p_{\mathrm{c}}, q_{\mathrm{c}}, r_{\mathrm{c}}$ と基準点における速度指令 值 $V_{\mathrm{ac}}$ が, 制御の目標値として入力される.ここでの制御 方式には, 目標值への追従性と安定性が確保されている限 り，各航空機ごとに信頼性が確立されている従来方式を用 いればよい，たとえば通常型の航空機では, 上記各指令値 に対して光れ光れ，エルロンまたはスポイラー角度，エレ ベータ角度, ラダー角度, およびエンジン出力の指令值を 操作量として，PID 制御則を基本とした制御を行うのが一 般的である .

\section{3. シミュレーション}

F16 戦閂機6) を対象としたときの，本稿で提案した制御 のコンピュータ・シミュレーションを，種々の目標経路に 対して行った . 機体の運動方程式には, 文献 6)に記載の非 線形モデルを用い，速度の目標值は $156 \mathrm{~m} / \mathrm{s}$ で一定，制御 開始時の高度は海抜 $0 \mathrm{~m}$ とした $, p, q, r$ の制御（姿勢制 御) においては，エルロン，エレベータ，ラダーを光れぞ れの制御の操作量とした PID 制御を，文献 6) を参考にし て構成し，ARI（ヨーイング防止のための，エルロンから ラダーへのフィードフォワード制御)，横滑り角 $\beta$ の制御 (目標値は 0)，ロールダンパ，ヨーダンパも設定した .

すべてのシミュレーションにおいて制御系は定数值も含 めて同じで, 経路と加速度のコントローラにおける制御周 期は 0.1 秒とした . (1) 式から (6) 式における制御定数值は つぎのように設定した .

$$
t_{\mathrm{amx}}=4.0[\mathrm{~s}], \quad r_{\mathrm{de}}=3.0,
$$

$$
\begin{array}{ll}
t_{\mathrm{ff}}=1.0[\mathrm{~s}], & t_{\mathrm{wa}}=1.0[\mathrm{~s}], \\
K_{\mathrm{aP}}=0.5, & K_{\mathrm{aI}}=0, \quad K_{\mathrm{aD}}=0.25
\end{array}
$$

迎角 $\alpha$, 横滑り角 $\beta$ および $\mathrm{G}$ フォース (g-f) の範囲は光れ 艺れ， $-5^{\circ} \leftrightarrow 20^{\circ},-4^{\circ} \leftrightarrow 4^{\circ},-1 \leftrightarrow 9[\mathrm{G}]$ に制限した .

以下に , 代表的な 3 つのシミュレーションケースを示す . 3 つのケースの目標経路等は下記のように設定した .

ケース 1 : バレルロール (らせん状回転, バレル半径 :

$244 \mathrm{~m})$ : 方位角 $45^{\circ}$ で水平飛行 $(122 \mathrm{~m}) \rightarrow$ バレルロー ル 2 回転 (らせん角 : 45 度) $\rightarrow$ (約 30 秒後) 方位角 $45^{\circ}$ で水平飛行.

ケース 2 : バレルロール (バレル半径 : $152 \mathrm{~m}$ ) : バレル半 径の他はケース 1 と同じ .

ケース 3 : 変形インメルマンターン (風外乱あり) : 方位 角 $0^{\circ}$ (北向き) で水平飛行 $(122 \mathrm{~m}) \rightarrow$ 方位角 $0^{\circ}$ で上 向き四分円 (半径 $518 \mathrm{~m}$ ) $\rightarrow$ 垂直上昇 $(244 \mathrm{~m}$ ) $\rightarrow$ 方位 角 $90^{\circ}$ (東向き) で上向き四分円 (半径 $518 \mathrm{~m}$ ) $\rightarrow$ (約 16 秒後) 方位角 $90^{\circ}$ て冰平飛行; 開始 20 秒後, 北方か ら風速 $30 \mathrm{~m} / \mathrm{s}$ のステップ状風外乱を受ける.

ここでバレルロールのらせん角とは, バレルロール中の速 度ベクトルとバレル軸方向とのなす角を意味する . 上記目 標経路はすべて滑らかな曲線であり，位置座標の $x, y, z$ 方向は光れ光れ，北，西，上方向に対応する.シミュレー ション時間は，ケース 1 を 40 秒，ケース 2,3 を 30 秒と した。

ケース 1 のシミュレーション結果を第 5 図〜第 8 図に示 す.まず第 5 図は 3 次元空間における飛行経路を, 第 6 図 は位置座標 $(x, y, z)$, 速度 $V_{\mathrm{a}}, \exists$ 一角 $\psi$ の時間的变化を， 第 7 図は迎角 $\alpha$, 横滑り角 $\beta$, ピッチ角速度 $q$, G フォース (g-f) の時間的変化を，第 8 図は航空機への制御入力 [エ レベータ・エルロン・ラダーの角度 $\left(\delta_{\mathrm{e}}, \delta_{\mathrm{a}}, \delta_{\mathrm{r}}\right)$, エンジ ン出力指令值 $\left.T_{\mathrm{hc}}\right]$ の変化を示している.

第 6 図より，位置誤差がほとんど発生せず，飛行経路は 目標に良好に追従していることがわかる．速度 $V_{\mathrm{a}}$ は，機 体上昇時には第 8 図に示す $T_{\mathrm{hc}}$ の上限のために減少し，下 降時には増加している。

一方第 7 図より迎え角 $\alpha$ は, バレル下端から上昇すると

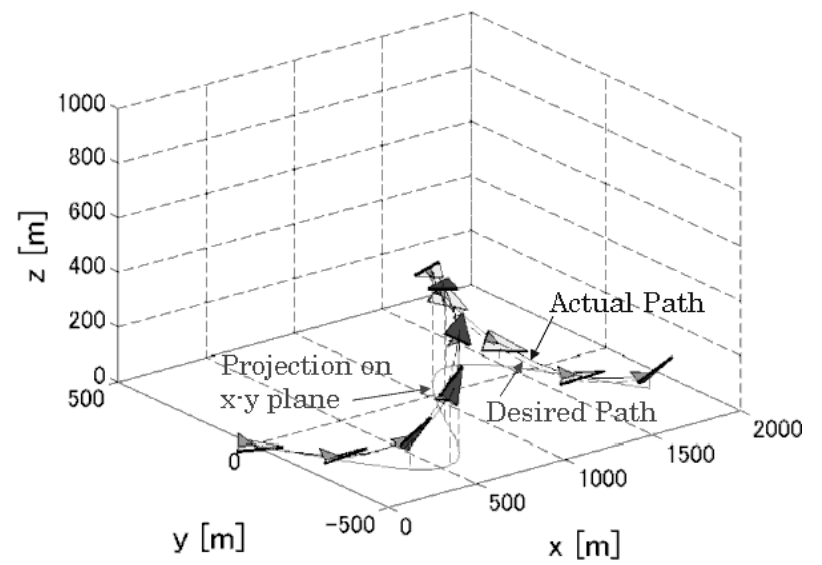

第 5 図 シミュレーションケース 1 (3 次元表示 ; 最初の 20 秒間) 


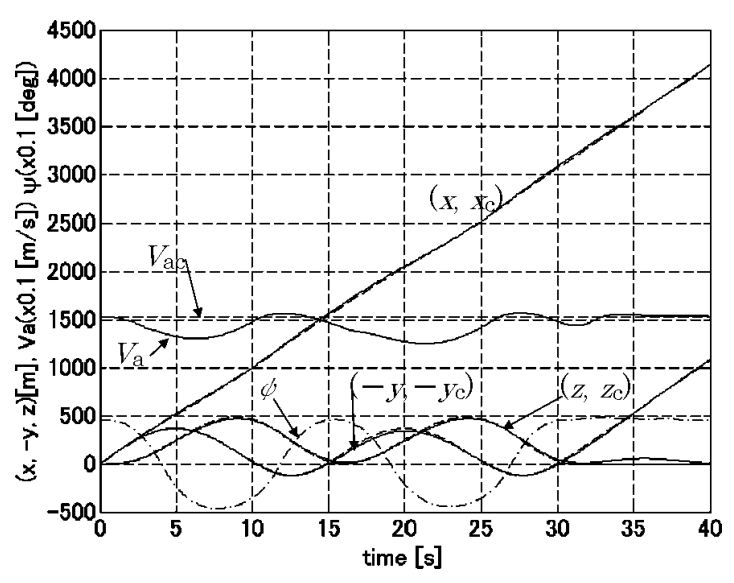

第6図 シミュレーションケース 1 (位置制御結果等)

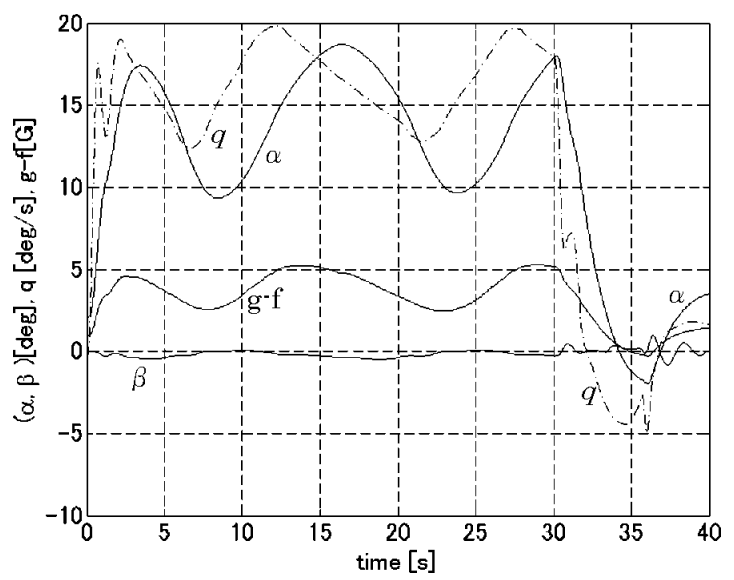

第 7 図 シミュレーションケース 1 (迎え角，横滑り角，他)

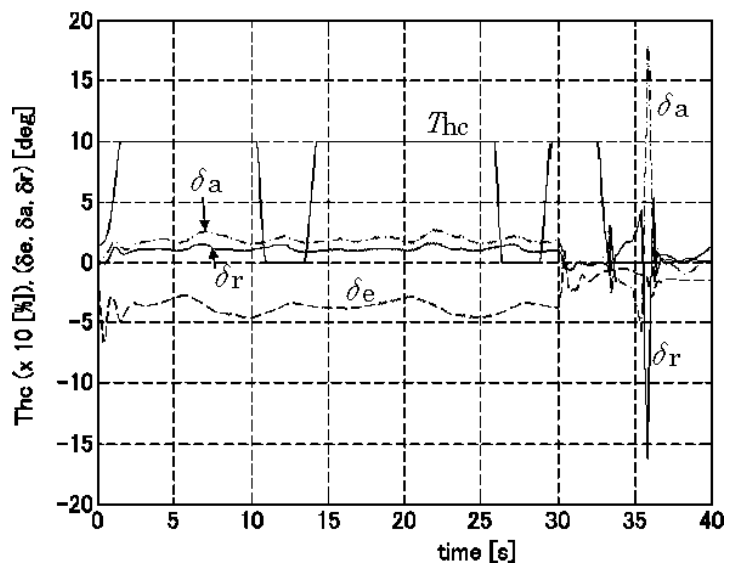

第 8 図 シミュレーションケース 1 (制御入力)

きに最大で, 上限の $20^{\circ}$ に近い, 横滑り角 $\beta$ は $-1.5^{\circ}$ 前 後で小幅に変動している. 第 8 図に示す制御入力はいずれ も妥当な変化をしている。

つぎにケース 2 のシミュレーション結果を，第 5 図〜第 7 図と同樣の第 9 図〜第 11 図に示す.このケースでは目標 経路曲率が飛行性能を超えている.第 9 図，第 10 図より， バレルロール中に位置制御誤差がかなり大きく発生したが， 目標経路が直線になった後は, 飛行経路は滑らかに目標に

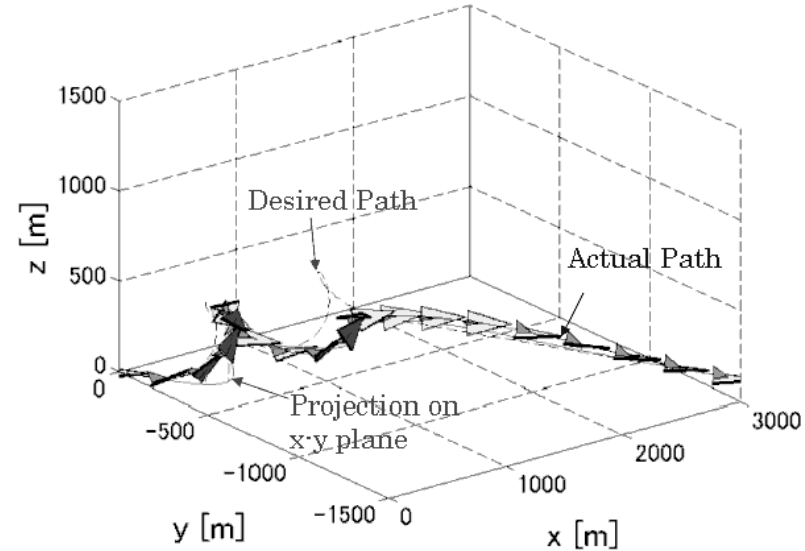

第 9 図 シミュレーションケース 2 (3 次元表示 ; 30 秒間)

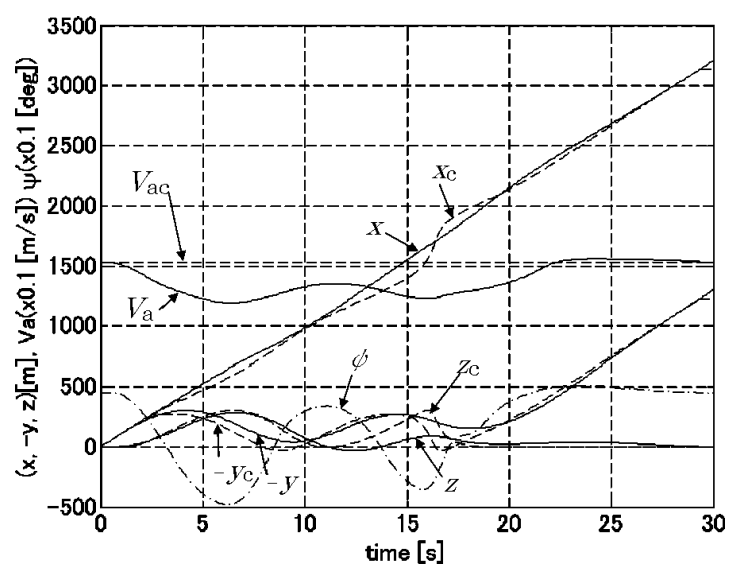

第 10 図 シミュレーションケース 2 (位置制御結果等)

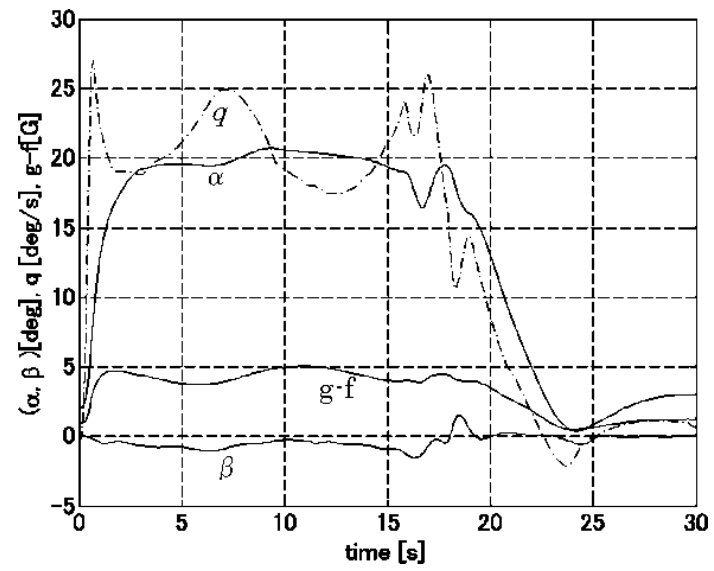

第 11 図 シミュレーションケース 2 (迎え角, 横滑り角, 他)

一致していることがわかる．すなわち，飛行経路が一時的 に目標をはずれても，本制御を用いれば，弚の後滑らかに 目標に復帰可能であることが示されている.第 11 図より迎 え角 $\alpha$ は, バレルロール中は上限の $20^{\circ}$ にほぼ等しく， $\alpha$ の上限規制が有効に働いていることがわかる .

つぎにケース 3 のシミュレーション結果を，第 5 图〜第 8 図と同樣の第 12 図〜第 15 図に示す . ケース 1 と同樣に , 飛行経路は目標に良好に追従していることがわかる. 速度 


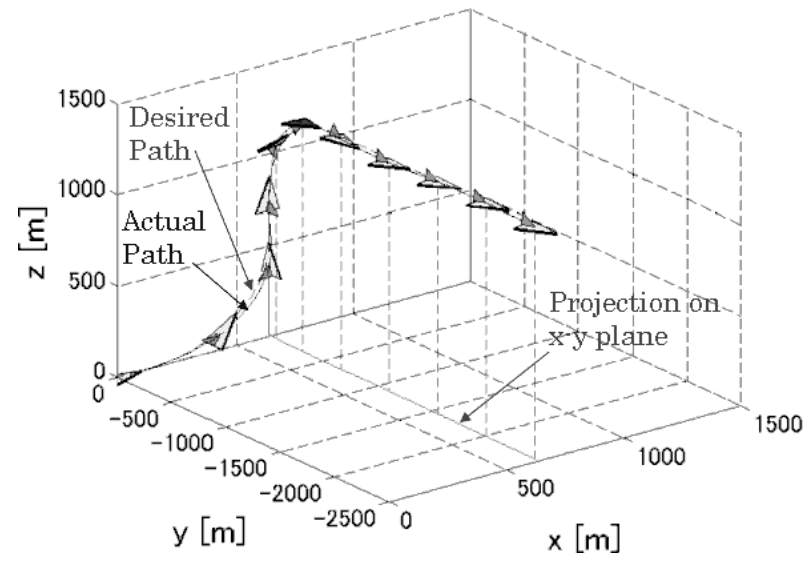

第 12 図 シミュレーションケース 3 (3 次元表示 ; 30 秒間)

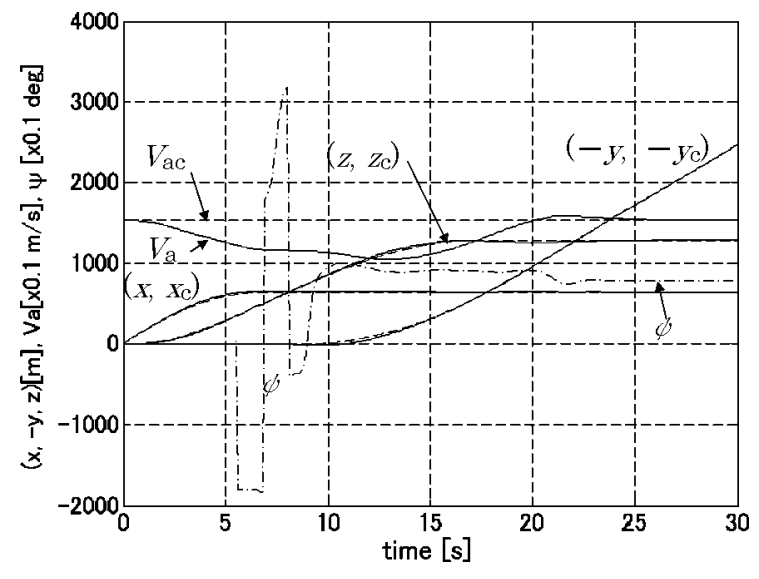

第 13 図 シミュレーションケース 3 (位置制御結果等)

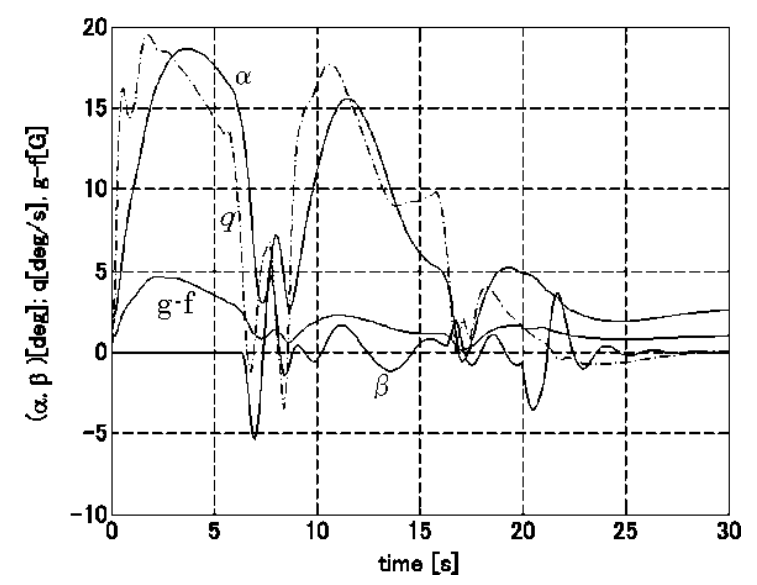

第 14 図 シミュレーションケース 3 (迎え角, 横滑り角，他)

$V_{\mathrm{a}}$ は, 機体上昇時には減少するが水平飛行に移行後は増加 して目標值に一致する . 時刻 20 秒のときにステップ状風外 乱か加わるが , 飛行経路はほとんど乱れない . 第 13 図の $\psi$ の值は外乱発生直前はほぼ $90^{\circ}$ (東方向) で, 外乱発生後 は $78^{\circ}$ に落ち着いた .すなわち風外乱発生と同時に機首を 進行方向より $12^{\circ}$ 風上へ向けて, 速やかに定常飛行に復帰

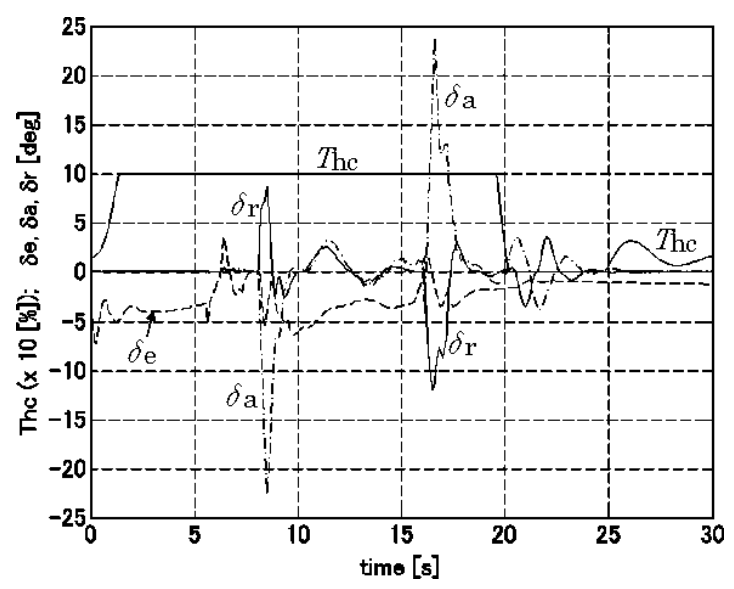

第 15 図 シミュレーションケース 3 (制御入力)

した

これらのシミュレーション結果により, 本経路制御が種々 の目標経路や風外乱に対して良好に働き，航空機位置が目 標経路から大きくはずれた場合には，滑らかに目標経路に 復帰可能であることが確認された .

\section{4. おわりに}

3 次元空間における航空機の飛行経路を制御する一方法 について述べた．本方法は以前に提案した方位角・経路角 制御を発展させたものであり，以前の方法と同樣に制御計 算では, 航空機の逆システムや空力微係数を必要としない. 本制御は階層構成になっていて, 下位の姿勢・速度制御に は従来方式を光のまま用いることができるため, 既存制御 の大きな変更なしに導入可能と思われる .

本制御では，従来提案されている経路制御と同樣に，航 空機の位置, 速度, 飛行方向, 姿勢の現在值を, 長くても 0.2 秒程度の制御周期で正しく把握できることを前提とし ているが，実際にはこれはかなり困難である .このため本 制御導入に際しては, 種々のセンサー情報に基づいた信号 処理による，上記の值の高精度推定が必要と思われる．測 定や推定の誤差が存在する場合の，本制御の精度やロバス 卜性の検討は今後の課題である .

\section{参 考 文 献}

1) 馬場順昭，宮本盛慈 : 与えられた経路のための飛行制御系，日本 航空宇宙学会誌 , 38 (1990), pp. 494-501.

2) 馬場順昭, 高野博行, 佐野正樹 : 航空機の目標経路への誘導と制 御，第 12 回誘導制御シンポジウム , 1995, pp. 147-154.

3) Steharu-Alexe, I. and O'Shea, J.: Four-Dimensional Guidance of Atmospheric Vehicles, J. Guid. Control Dynam., 19 (1996), pp. 113-122.

4）高野博行, 越智信介, 馬場順昭 : アクロバット飛行の最適化につ いて,第 38 回飛行機シンポジウム講演集, 2000, pp. 93-96.

5）芳谷直治：必要加速度ベクトルに基づいた，航空機の方位角・経 路角制御の一方法, 日本航空宇宙学会論文集, 52 (2004), pp. 265-271.

6) Stevens, B. L. and Lewis, F. L.: Aircraft Control and Simulation, John Wiley \& Sons, New York, 1992. 